The psychic costs of migration: evidence from Irish return migrants

Author(s): Alan Barrett and Irene Mosca

Source: Journal of Population Economics, Vol. 26, No. 2 (April 2013), pp. 483-506

Published by: Springer

Stable URL: https://www.jstor.org/stable/23354338

Accessed: 31-07-2019 09:28 UTC

JSTOR is a not-for-profit service that helps scholars, researchers, and students discover, use, and build upon a wide range of content in a trusted digital archive. We use information technology and tools to increase productivity and facilitate new forms of scholarship. For more information about JSTOR, please contact support@jstor.org.

Your use of the JSTOR archive indicates your acceptance of the Terms \& Conditions of Use, available at https://about.jstor.org/terms

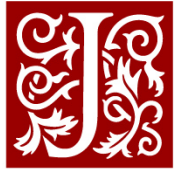




\title{
The psychic costs of migration: evidence from Irish return migrants
}

\author{
Alan Barrett • Irene Mosca
}

Received: 29 November 2011 / Accepted: 11 July 2012 /

Published online: 23 August 2012

(C) Springer-Verlag 2012

\begin{abstract}
Within the economics literature, the 'psychic costs' of migration have been incorporated into theoretical models since Sjaastad (J Polit Econ 70:80 93, 1962). However, the existence of such costs has rarely been investigated in empirical papers. In this paper, we look at the psychic costs of migration by using alcohol problems as an indicator. Rather than comparing immigrants and natives, we look at the native-born in a single country and compare those who have lived away for a period of their lives and those who have not. We use data from the first wave of the Irish Longitudinal Study on Ageing which is a large, nationally representative sample of older Irish adults. We find that men who lived away are more likely to have suffered from alcohol problems than men who stayed. For women, we again see a higher incidence of alcohol problems for short-term migrants. However, long-term female migrants are less likely to have suffered from alcohol problems. For these women, it seems that migration provided psychic benefits, and this is consistent with findings from
\end{abstract}

Responsible editor: Klaus F. Zimmermann

Electronic supplementary material The online version of this article (doi:10.1007/s00148-012-0438-4) contains supplementary material, which is available to authorized users.

A. Barrett (凶) - I. Mosca

The Irish Longitudinal Study on Ageing (TILDA),

Trinity College Dublin, Dublin 2, Ireland

e-mail: barretal@tcd.ie

\section{A. Barrett - I. Mosca}

Economic and Social Research Institute (ESRI),

Dublin 2, Ireland

\section{A. Barrett}

Institute for the Study of Labor (IZA), Bonn, Germany 
other research which showed how migration provided economic independence to this group. The results remain when we adjust for endogeneity and when we use propensity score matching methods.

Keywords Return migrants • Older adults • Ireland • Alcoholism

\section{Introduction}

Many papers in the economics literature on migration begin with the following simple behavioural model. Individuals are characterised by comparing the lifetime streams of earnings in origin and destination countries. Migration occurs (assuming no legal constraint) if the difference in the lifetime earning streams in the country of destination and origin is greater than the costs of migration. These costs of migration are assumed to include pecuniary expenses such as travel costs but also non-pecuniary elements such as 'psychic costs'. This term refers to the emotional impact of leaving family and friends and having to cope with life in an unfamiliar and potentially hostile environment. ${ }^{1}$

A huge volume of research has been generated around the labour market experiences of immigrants, such as their earnings and occupational attainment, reflecting the importance of earnings in the basic theoretical formulation. However, the issue of psychic costs has generally received a lot less attention, at least in the economics literature. ${ }^{2}$ The resulting research gap strikes us as being potentially important. To the extent that the psychic costs of migration differ across groups, they should help to explain patterns of migration. In addition, if the psychic costs of migration are unexpectedly high for those who have migrated, this could result in a failure on the part of migrants to succeed, for example, in the host country labour market.

In broad terms, we approach the issue in the following way. Using data from the first wave of the Irish Longitudinal Study on Ageing (TILDA), we compare Irish people who have lived outside of Ireland for a period of time (return migrants) with a group who have not done so (stayers). By using alcohol dependence as an indicator of having experienced elevated psychological stress at some point over one's lifetime, we can assess the extent to which such problems are reported more frequently by return migrants relative to stayers. This approach of comparing people of the same nationality offers a big advantage relative to other studies which compare immigrants with natives

\footnotetext{
${ }^{1}$ Faini and Venturini (2010) refer to the related concept of 'home bias' and the 'highly idiosyncratic preferences that have been formed while living in (the) area of origin'.

${ }^{2}$ As discussed in the literature review, papers have appeared in the medical literature which looks at the mental health status of immigrants relative to natives. However, the approach here offers a number of advantages relative to this earlier work and also places the work more firmly in the economics literature.
} 
in a country. The 'treatment' and 'control' groups here should be much more similar, and so any findings on differences between the two groups are more likely to be related to migration. In addition, our data allow us to control for early traumatic events in the lives of the survey respondents such as physical or sexual abuse in childhood. As such events are likely to be correlated with both migration and psychological problems, an inability to control for them would be a weakness and could lead to over-estimate the psychic costs of migration. We use standard probit models but also adjust for potential endogeneity using instrument variable (IV) methods. We also use propensity score matching and arrive at similar results, regardless of the approach taken.

The remainder of the paper is structured as follows. In Section 2, we review the literature on the association between (return) migration and psychological health. In Section 3, we investigate historical Irish migration and, in particular, the literature on the experiences of the Irish abroad in the second half of the twentieth century. In Section 4, we describe the data used in the empirical analysis. In Section 5, we illustrate the methodology employed in our paper. In Sections 6 and 7, we present both descriptive statistics and the results from the econometric analysis. In Section 8 , we investigate whether return migrants could be 'failed migrants'. Section 9 provides some conclusions.

\section{Psychic costs of (return) migration}

In this paper, we argue, in line with the international literature, that both first migration and return migration can impact negatively on migrants' psychological health.

Several international studies, mainly in the medical and demography literature, have investigated the association between migration and mental health by comparing mental health outcomes of the native-born population with those of the immigrant population. Anxiety, depression and an increased risk for psychotic disorders have been reported to be prevalent in some migrant populations (Odegaard 1932; Coid et al. 2008; Silveira et al. 2002; Aichberger et al. 2010; Bhugra 2004). These findings are explained, at least to some extent, in terms of higher social adversity, migrant stress, social isolation, depression, loneliness and poor living conditions of the migrant populations. Focusing on the experiences of Irish migrants living in Britain in the second half of the twentieth century, the sociological literature has revealed high levels of social deprivation and poor health for Irish migrants, especially for men (Leavey et al. 2004; Commander et al. 1999; Harrison and Carr-Hill 1992; Mullen et al. 1996; Pearson et al. 1991; Cochrane and Bal 1989; Nazroo 1997).

Not only the first migration experience but also return migration can be a stressful event and can impact negatively on mental health. The re-adjustment experiences of return migrants in their home countries have received some attention in the sociological literature. Many studies have highlighted the sense of disappointment, isolation and feelings of alienation and not-belonging 
experienced by return migrants (Constable 1999; Long and Oxfeld 2004; Christou 2006; Cerase 1970, 1974). In the Irish context, two studies are of particular interests: that of Gmelch $(1986,1987)$ and of McGrath (1991).

In 1977-1978, Gmelch $(1986,1987)$ and collaborators interviewed 606 Irish migrants who had lived abroad for at least 2 years and then settled down in small communities in the west of the country. Fifty-one percent of return migrants stated that they were not satisfied with their lives back in Ireland during their first year back. This compares to $21 \%$ for those who had been back for two or more years and $17 \%$ for those who had been back for more than 5 years. The difficulties encountered in re-establishing relationships increased with the time spent abroad. Eighty-five percent of respondents stated they felt different from stayers.

McGrath (1991) investigated the experiences of 142 return migrants who moved back to the west of Ireland. Eighty-two of respondents returned to their home towns and $74 \%$ to their parents' house. Most returners faced a range of different re-adjustment problems, including the poor economic situation and lack of employment opportunities; lack of variety in shopping; the unfriendly attitude of locals; and the inefficiency and slow pace of island life.

\section{Historical overview of Irish migration}

The topic on migration has been of enormous importance for Ireland since the early part of the last century. For much of the twentieth century, emigration from Ireland was high, and population decline continued until 1961. But even in the 1960s when the population grew, emigration continued. The 1970s saw unprecedented inflows, but net outflows resumed in the 1980s, thereby leaving emigration as a defining feature of Ireland's demographic and economic experience.

Table 1 shows that, on an annual basis, net outward migration averaged 14.1 per 1,000 of the population in the $1950 \mathrm{~s}$ and 4.6 per 1,000 in the $1960 \mathrm{~s}$. These

Table 1 Net migration flows and rates in Ireland, 1926-1991 (annual averages)

\begin{tabular}{lcccc}
\hline Intercensal period & \multicolumn{2}{l}{ Net migration } & \multicolumn{2}{c}{$\begin{array}{l}\text { Net migration rate over } \\
1,000 \text { average population }\end{array}$} \\
\cline { 2 - 4 } & Males & Females & Total & -5.6 \\
\hline $1926-1936$ & $-7,255$ & $-9,420$ & $-16,675$ & -6.3 \\
$1936-1946$ & $-11,258$ & $-7,453$ & $-18,711$ & -8.2 \\
$1946-1951$ & $-10,309$ & $-14,075$ & $-24,384$ & -14.1 \\
$1951-1961$ & $-21,786$ & $-19,091$ & $-40,877$ & -4.6 \\
$1961-1971$ & $-6,236$ & $-7,215$ & $-13,451$ & +3.2 \\
$1971-1981$ & $+5,806$ & +4583 & $+10,389$ & -5.9 \\
$1981-1991$ & $-8,283$ & $-6,094$ & $-14,377$ & -5.6 \\
$1926-1936$ & $-7,255$ & $-9,420$ & $-16,675$ & -6.3 \\
$1936-1946$ & $-11,258$ & $-7,453$ & $-18,711$ & \\
\hline
\end{tabular}

Source: 1926-1986 taken from NESC (1991); 1986-91 from Sexton (1996) 
outflows were counterbalanced by net inflows in the 1970 s $(3.2$ per 1,000$)$. However, net outward migration averaged 5.9 per 1,000 of the population in the 1980s.

With regard to the destinations of Ireland's emigrants, a major shift occurred at the beginning of the 1930s. Between 1880 and $1921,87 \%$ of emigrants went to the USA, whereas only $10 \%$ went to Britain. However, it is estimated that by the late 1940 s, over $80 \%$ of the outflow went to Britain, and this continued in the 1970s (Barrett 2005). The outflow was concentrated in the 15-24-year age category, and so emigration was a young person's pursuit. Also, most migrants left as single people (Leavey et al. 2004).

The literature on the Irish experience in Britain has revealed that most individuals migrated for economic reasons, although this generally co-existed with a 'pull' factor of desire to escape or change (Gmelch 1986, 1987; Ryan 2004; Leavey et al. 2004).

Turning to the occupation of migrants, Hughes and Walsh (1976) reported that a third of male migrants were 'construction workers' or 'labourers n.e.c. (not elsewhere classified)'. Nearly $60 \%$ were in the skilled, semiskilled and unskilled manual socioeconomic group. The occupation distribution reveals a higher occupational status for Irish women in Britain than for Irish men. Walter (1989) reported that by the 1960 s, $11 \%$ of all nurses recruited in hospitals in the southeast of England were born in Ireland. Similarly, Daniels (1993) reported that by 1971, there were 31,000 Irish-born nurses in Britain, constituting $12 \%$ of all nursing staff.

\section{Data}

Data from the first wave (2009/2011) of TILDA is used. This is a study of people aged 50 and over (and of their spouses or partners of any age) resident in Ireland. TILDA collects detailed information on all aspects of the respondents' lives, including the economic dimension (pensions, employment, living standards), health aspects (physical, mental, service needs and usage) and the social domain (contact with friends and kin, formal and informal care, social participation). The study is closely harmonised with leading international longitudinal studies of ageing (e.g. The English Longitudinal Study of Ageing; the Survey of Health, Ageing and Retirement in Europe, which is panEuropean; and the Health and Retirement Survey conducted in the USA).

Data collected in TILDA is made of three components: the computer-aided personal interview (CAPI) questionnaire; the self-completion questionnaire (SCQ), designed to explore certain areas that were considered particularly sensitive for respondents to answer directly to an interviewer; and the health assessment component of the study, conducted both in dedicated TILDA health assessment centres and, alternatively, in respondents' homes.

The first wave of TILDA includes 8,507 respondents. In the CAPI questionnaire, individuals are asked about their nationality and, for the purpose of this analysis, the sample is restricted to Irish nationals only. TILDA also collects 
information on previous migration experiences. In particular, individuals residing in Ireland are asked if they have ever lived outside Ireland for at least 6 months. If they answer yes, individuals are coded as 'return migrants'; if they answer no, then individuals are coded as 'stayers'.

Also, information on the total number of years spent abroad and age at first migration is collected. Using the information on the total number of years spent abroad, we divide return migrants into two categories: (a) short-term return migrants and (b) long-term return migrants. We investigated different cutoff points to distinguish between short-term and long-term return migrants. In the models which follow, short-term migrants are classified as those who lived abroad for 1-9 years and long-term migrants are classified as those who lived in another country for 10 years or more. However, if a lower cutoff point was to be chosen (e.g. 5 years), the results of our models would not change significantly.

In the TILDA sample, $24 \%$ of men and $21 \%$ of women have lived abroad for at least 6 months. Forty six percent of the male return migrants and $43 \%$ of female return migrants have lived abroad for at least 10 years. Sixty seven percent of men and $74 \%$ of women left Ireland for the first time at age 16-24.

\section{Methodology}

TILDA includes a wide battery of questions on current mental health, with respondents being asked to describe the ways they have felt or behaved in the last week or month. Unfortunately, current mental health is not a good measure to capture psychic costs of migration, especially because many (return) migrants emigrated/returned to Ireland many years prior to the interview. We need a variable that captures possible episodes of mental health problems which may have occurred over the lifetime. TILDA respondents are also asked to state whether they have ever been diagnosed by the doctor with any emotional, nervous or psychiatric problems, such as depression and anxiety, and/or alcohol or substance abuse. Due to the differences in the medical systems between Ireland and other countries-especially the UK, where most of the return migrants in our sample spent a part of their life-we argue that using a variable which focuses only on doctor diagnosis of mental health problems might lead to biassed results.

In our basic specification, we focus on diagnosed/self-reported alcohol problems to model the psychic costs of migration. We begin with a standard probit model of the following form:

$$
\operatorname{Pr}(A=1)=f n(X, \text { return migrant })
$$

where $A$ is the outcome variable and is equal to one if the respondent suffers/has ever suffered from an alcohol problem; otherwise, zero. $X$ is a set 
of controls including both standard socioeconomic characteristics and negative life events in childhood (discussed below). Return migrant is a dummy variable equal to one if the individual has lived away for a period of time and zero otherwise.

Alcohol problems, the outcome variable, are identified when the respondent

(1) reports having been diagnosed with an alcohol or substance abuse problem at some stage in life. If this is the case, the respondent is asked to state when the diagnosis was made. For migrants, we exclude from the sample those who were diagnosed before migration; and/or

(2) scores highly in the cut-annoyed-guilty-eye (CAGE) questionnaire. The CAGE questionnaire, which is a module of the SCQ in TILDA, is a screening test for alcohol problems and has been extensively validated for use in identifying alcoholism (Mayfield et al. 1974; Kitchens 1994). It was designed as a tool for identifying 'the hidden alcoholic' and to address the tendency of physicians to omit alcohol abuse from diagnostic considerations (Ewing and Rouse 1970; Ewing 1984, 1998). ${ }^{3}$

The CAGE questionnaire consists of four questions evaluating alcohol patterns and behaviour. Respondents are asked to state (1) if they ever felt that they should cut down on drinking (cut); (2) if people have ever annoyed them by criticising their drinking (annoyed); (3) if they ever felt bad or guilty about drinking (guilty); and (4) if they have ever taken a drink first thing in the morning to steady their nerves or get rid of an hangover (eye-opener). The test score varies from a minimum of zero to a maximum of four: zero if the respondent answers no to all the fours questions, four in the opposite case. As highlighted by Ewing (1998), there is not a standard cutoff point to identify alcohol problems. Bernadt et al. (1982) concluded that a test score equal or greater than two had a sensitivity of $93 \%$ and a specificity of $76 \%$ for the identification of problem drinkers. However, Bradley et al. (1998) argued that for women, the reasonable cut point is answering positively to one or more questions. Hence, different cutoff points are investigated in our model.

Ideally, it would have been helpful to know that any reported alcohol problems began after migration had occurred. In the case of the doctor diagnosis, we do know the date of diagnosis and so can exclude those whose diagnosis occurred before migration. In the case of the CAGE, we cannot pin-point dates, but it should be noted that most of the people in the sample left Ireland in their late-teens and early 20 s. Hence, the scope for them to have developed

\footnotetext{
${ }^{3}$ For example, in a national survey of 648 primary care physicians carried out by the National Center of Addiction and Substance Abuse (2000), physicians were given case records of patients with a history typical of alcohol abuse. Physicians were asked to list five possible diagnoses. Whilst most physicians listed ulcer and irritable bowel syndrome, only $6.2 \%$ correctly identified substance abuse as one of the five possible diagnoses.
} 
alcohol problems before migration would be limited, and so for the vast bulk of our sample, any alcohol problem would have begun after migration.

Turning to the explanatory variables, we control for return migration distinguishing between short-term and long-term migration. We include two dummy variables in the model: a dummy variable equal to one if the individual is a stayer, zero otherwise (reference category); a dummy variable equal to one if the individual is a short-term migrant (1-9 years spent abroad), zero otherwise; and a dummy variable equal to one if the individual is a long-term migrant (ten or more tears spent in another country), zero otherwise.

We then control for 'standard' socioeconomic characteristics that are associated with the outcome variable. These include the following:

- Age (single year of age)

- Household composition, in three categories: currently lives alone; currently lives with spouse only; and currently lives with others, including children, grandchildren, siblings etc.

- Educational attainment on highest qualification attained, in three categories: primary or none, secondary and third or higher ${ }^{4}$

- Parental education on highest qualification attained, in three categories: both parents completed primary education; education is missing for at least one parent; and at least one parent completed secondary or tertiary education and education is not missing for the other parent.

- Socioeconomic status in childhood on dummy variables for whether none of the respondent's parents ever worked outside the home when the respondent was aged less than 14 ; the respondent was living in a rural area at age 14; or the respondent grew up in a poor family

- Health in childhood: a dummy variable for whether the respondent selfrates her health in childhood (from birth to age 14) as poor

- Current area of residence, in three categories: Dublin; town/city other than Dublin; and rural area

- Current self-reported labour market status, in five categories: employed, retired; permanently sick or disabled; unemployed; and other

- Smoking, in three categories: never smoked, used to smoke but quit and currently smokes

Besides controlling for standard socioeconomic characteristics and migration, we are also able to control for negative life events in childhood. The association between negative early life events and later life mental health problems is well documented in the literature. Numerous studies have shown that adult mental health consequences of negative early life events-such as childhood abuse,

\footnotetext{
${ }^{4}$ In TILDA, education is measured by the highest level of formal education achieved. Irishspecific levels are reclassified into three categories: primary/none (not complete or primary or equivalent), secondary (intermediate/junior/group certificate or equivalent and leaving certificate or equivalent) and third/higher (diploma/certificate, primary degree and postgraduate/higher degree).
} 
death of a parent and poor socioeconomic circumstances-include depression, anxiety disorders and substance abuse (Springer et al. 2003; Arnow 2004; Batten et al. 2004; Draper et al. 2008; Kraaij et al. 2002).

In the SCQ, TILDA respondents are asked to report whether before turning 18 they were either physically or sexually abused by either their parents or anybody else and whether their parents drank or used drugs so often that it caused problems in the family. In the CAPI, information on respondents' age at parents' death is also collected. This enables us to compute three additional dummy variables, capturing if before turning 18 the respondent

- was physically or sexually abused

- was living in an household in which the parents drank or used drugs so often that it caused problems in the family

- lost at least one parent

Unsurprisingly, the number of missing observations for the negative early life events is significantly higher than for the other controls. To avoid losing important information, we include three dummies for each event: (1) event occurred; (2) event did not occur; (3) respondent did not provide information on the specific event (with 2) being the reference category.

A key empirical problem we are facing is the potentially endogenous nature of the migration variable. The intuitive justification is that migration might be endogenous if the decision to migrate is correlated with unobservables that affect the outcome variable. If returners and stayers differ in unobservable factors that are correlated with the outcome variable, a standard probit model may generate a biassed estimate of the coefficient of the migration variable. The use of negative early life events helps us to control for endogeneity. Usually, information on negative early life events is not collected in (migration) surveys. As a consequence, life events are normally confined to the error term but are a potential source of endogeneity if they are correlated with both migration and the outcome variable.

However, even the inclusion of controls for negative life events may not be sufficient to account for unobservables. Hence, we also use an instrumental variable approach to explore more fully possible endogeneity problems. A key element in running this procedure is the identification of a variable which is correlated with the likelihood of being a return migrant but not with the error term in the outcome equation. As an instrument, we use the net migration rates in the years in which the individuals in our sample would have been deciding whether to migrate or not. As will be seen below, this instrument works well, and our key results remain even when we control for endogeneity. ${ }^{5} \mathrm{We}$ also use

\footnotetext{
${ }^{5}$ Barrett and Goggin (2010) use unemployment rates in the year individuals left full-time education as an instrument in an analysis of the wages of return migrants relative to stayers. They argue that this captures economic conditions and hence is likely to influence migration decisions. Our use of net outward migration rates is similarly motivated.
} 
propensity score matching as a further robustness check and, again, support for the key results is found.

\section{Descriptive statistics}

We use variables from both the CAPI and the self-completion questionnaires and restrict our sample to respondents who have completed both. As previously mentioned, we exclude respondents who were not born in Ireland. We are left with a final sample of 2,770 men and 3,244 women. For men, $76.1 \%$ are stayers and $23.9 \%$ are return migrants. The corresponding figures for women are 78.9 and $21.1 \%$, respectively.

\subsection{Men}

In Table 2, we report the mean values (and standard deviations) of all the variables used in our analysis for males. These are presented separately for (a) stayers; (b) short-term return migrants, i.e. those who lived abroad for 1-9 years; and (c) long-term return migrants, i.e. those who lived in another country for 10 years or more. Short-term (54\%) and long-term (46\%) migrants are looked at separately because, as the results in Table 2 show, there are important statistically significant differences between the two groups and in turn with stayers.

Focusing first on the outcome variables, Table 2 shows that returners are more likely to suffer/have suffered from an alcohol problem. Of stayers, $7.6 \%$ have/had an alcohol problem, when this is identified as having been diagnosed by the doctor with an alcohol or substance abuse problem and/or score 3 or more in the CAGE questionnaire. This compares to $15.0 \%$ for shortterm return migrants and $12.5 \%$ for long-term return migrants $(p<0.01)$. As expected, the proportion of men suffering from an alcohol problem decreases as the threshold/cutoff point to identify alcohol problems is increased. It is interesting to note that a non-negligible proportion of migrants (around $7 \%$ ) is/has been affected by an alcohol problem when the threshold is increased to answering affirmatively to all four questions of the CAGE questionnaire.

Turning to the explanatory variables, Table 2 shows that short-term and long-term migrants have different characteristics and in turn differ across a range of variables when compared to stayers. Long-term migrants are more likely to be older and poorly educated, have grown up in a poor family or in a rural area and be retired or live alone. On the other hand, short-term migrants are more likely to be highly educated, come from a family in which at least one parent is highly educated and are less likely to have grown up in a rural area.

Turning finally to negative early life events, Table 2 shows that $9.3 \%$ of stayers report having been sexually or physically abused before turning 18 , compared to $15.7 \%$ of short-term return migrants $(p<0.01)$ and $10.2 \%$ of 
Table 2 Descriptive statistics on male stayers, short-term migrants and long-term migrants

\begin{tabular}{|c|c|c|c|c|c|c|}
\hline & \multirow[t]{2}{*}{ Stayers } & \multirow[t]{2}{*}{ SD } & \multicolumn{4}{|l|}{ Migrants } \\
\hline & & & $\begin{array}{l}\text { Short-term } \\
\text { migrants }\end{array}$ & SD & $\begin{array}{l}\text { Long-term } \\
\text { migrants }\end{array}$ & SD \\
\hline \multicolumn{7}{|l|}{ Outcome variable(s): alcohol problem } \\
\hline Doctor diagnosis and/or CAGE $\geq 2$ & 0.159 & 0.366 & $0.257 * * *$ & 0.438 & $0.214 * *$ & 0.411 \\
\hline Doctor diagnosis and/or CAGE $\geq 3$ & 0.076 & 0.265 & $0.150 * * *$ & 0.357 & $0.125^{* * *}$ & 0.331 \\
\hline Doctor diagnosis and/or $\mathrm{CAGE}=4$ & 0.033 & 0.178 & $0.069 * * *$ & 0.253 & $0.074 * * *$ & 0.263 \\
\hline \multicolumn{7}{|l|}{ Explanatory variables } \\
\hline Age & 63.285 & 9.983 & 62.671 & 0.435 & $65.019 * * *$ & 8.574 \\
\hline \multicolumn{7}{|l|}{ Household composition } \\
\hline Lives alone & 0.199 & 0.399 & 0.169 & 0.376 & $0.306 * * *$ & 0.461 \\
\hline Lives with spouse only & 0.390 & 0.488 & 0.431 & 0.496 & $0.451^{*}$ & 0.498 \\
\hline Lives with other & 0.411 & 0.492 & 0.400 & 0.490 & $0.244 * * *$ & 0.430 \\
\hline \multicolumn{7}{|l|}{ Education } \\
\hline None/primary & 0.405 & 0.491 & $0.300 * * *$ & 0.459 & $0.509 * * *$ & 0.501 \\
\hline Secondary & 0.439 & 0.011 & 0.396 & 0.490 & $0.354 * * *$ & 0.479 \\
\hline Third/higher & 0.156 & 0.363 & $0.304 * * *$ & 0.460 & 0.137 & 0.344 \\
\hline \multicolumn{7}{|l|}{ Parental education } \\
\hline Both parents low education & 0.688 & 0.463 & $0.581 * * *$ & 0.494 & 0.694 & 0.462 \\
\hline $\begin{array}{l}\text { At least } 1 \text { parent } \\
\text { secondary/tertiary education }\end{array}$ & 0.230 & 0.421 & $0.313 * * *$ & 0.464 & 0.230 & 0.422 \\
\hline 1 parent missing education & 0.082 & 0.274 & 0.106 & 0.308 & 0.076 & 0.265 \\
\hline \multicolumn{7}{|l|}{ Socioeconomic status in childhood } \\
\hline Neither parent worked & 0.056 & 0.231 & 0.060 & 0.237 & 0.072 & 0.259 \\
\hline Grew up in rural area & 0.622 & 0.485 & 0.604 & 0.490 & $0.704 * * *$ & 0.457 \\
\hline Grew up in poor family & 0.241 & 0.428 & 0.257 & 0.438 & $0.386 * * *$ & 0.488 \\
\hline Poor health in childhood & 0.053 & 0.224 & 0.065 & 0.248 & 0.064 & 0.245 \\
\hline \multicolumn{7}{|l|}{ Current place of residence } \\
\hline Dublin & 0.227 & 0.419 & 0.262 & 0.440 & $0.109 * * *$ & 0.313 \\
\hline Town or city other than Dublin & 0.272 & 0.445 & $0.326^{* *}$ & 0.469 & 0.306 & 0.462 \\
\hline Rural area & 0.499 & 0.500 & $0.412 * * *$ & 0.493 & $0.581 * *$ & 0.494 \\
\hline \multicolumn{7}{|l|}{ Labour market status } \\
\hline Retired & 0.407 & 0.491 & 0.412 & 0.493 & $0.481 * *$ & 0.500 \\
\hline Employed & 0.456 & 0.498 & 0.449 & 0.498 & $0.314^{* * *}$ & 0.465 \\
\hline Permanently sick or disabled & 0.050 & 0.218 & 0.052 & 0.223 & $0.082 *$ & 0.275 \\
\hline Unemployed & 0.073 & 0.260 & 0.053 & 0.224 & 0.098 & 0.298 \\
\hline Other & 0.014 & 0.119 & $0.033^{* *}$ & 0.180 & 0.025 & 0.156 \\
\hline \multicolumn{7}{|l|}{ Smoking } \\
\hline Currently smokes & 0.167 & 0.373 & 0.190 & 0.393 & $0.257 * * *$ & 0.438 \\
\hline Used to smoke & 0.440 & 0.496 & $0.503 * *$ & 0.501 & $0.516^{* *}$ & 0.501 \\
\hline Never smoked & 0.393 & 0.489 & $0.307 * * *$ & 0.462 & $0.227 * * *$ & 0.420 \\
\hline \multicolumn{7}{|l|}{ Negative early life events } \\
\hline Parents had alcohol/drug problem & 0.075 & 0.263 & $0.133 * * *$ & 0.340 & 0.071 & 0.257 \\
\hline Parents had no alc./drug problem & 0.903 & 0.296 & $0.855^{* *}$ & 0.353 & 0.894 & 0.309 \\
\hline Missing information & 0.022 & 0.147 & 0.012 & 0.110 & 0.036 & 0.185 \\
\hline Physically or sexually abused & 0.093 & 0.290 & $0.157 * * *$ & 0.364 & 0.102 & 0.303 \\
\hline Not physically or sexually abused & 0.880 & 0.325 & $0.824 * * *$ & 0.381 & 0.875 & 0.331 \\
\hline
\end{tabular}

long-term-migrants. Also, $7.5 \%$ of stayers report that their parents drank/took drugs so often that it caused problems in the family, compared to $13.3 \%$ of short-term migrants $(p<0.01)$ and $7.1 \%$ of long-term migrants. This supports the view that, although economic reasons were a key determinant of emigration from Ireland in the second half of the twentieth century, the desire 
Table 2 (continued)

\begin{tabular}{|c|c|c|c|c|c|c|}
\hline & \multirow[t]{2}{*}{ Stayers } & \multirow[t]{2}{*}{ SD } & \multicolumn{4}{|l|}{ Migrants } \\
\hline & & & $\begin{array}{l}\text { Short-term } \\
\text { migrants }\end{array}$ & SD & $\begin{array}{l}\text { Long-term } \\
\text { migrants }\end{array}$ & SD \\
\hline Missing information & 0.027 & 0.162 & 0.019 & 0.137 & 0.024 & 0.152 \\
\hline $\begin{array}{l}\text { Parent(s) died when respondent } \\
\text { was }<18\end{array}$ & 0.141 & 0.349 & 0.132 & 0.339 & 0.128 & 0.335 \\
\hline $\begin{array}{l}\text { Parents did not die when } \\
\text { respondent was }<18\end{array}$ & 0.792 & 0.406 & 0.807 & 0.395 & $0.738^{* *}$ & 0.441 \\
\hline Missing information & 0.067 & 0.250 & 0.061 & 0.240 & $0.134 * * *$ & 0.342 \\
\hline Number & 2,067 & & 400 & & 303 & \\
\hline
\end{tabular}

Statistically significant differences between short-term migrants and stayers and long-term migrants and stayers are reported

${ }^{*} p<0.10 ;{ }^{* *} p<0.05 ;{ }^{* *} p<0.01$ (Data are weighted)

to escape problematic circumstances might have also played an important role.

\subsection{Women}

As expected, the proportion of women who suffer(ed) from an alcohol problem is lower for women than for men, so different CAGE cutoff points are investigated (i.e. 1, 2 and 3). Table 3 shows that a different picture emerges for women: short-term and long-term female migrants differ in terms of alcohol problems. Compared to stayers, short-term migrants are more likely to suffer/have suffered from an alcohol problem. On the contrary, long-term migrants are less likely to be affected by this kind of problem. For example, $8.1 \%$ of stayers have/have had an alcohol problem (when this is identified as having been diagnosed with an alcohol or substance abuse problem and/or score two or more in the CAGE questionnaire). This compares to $13.4 \%$ for short-term return migrants and $3.1 \%$ for long-term return migrants $(p<0.01)$.

Table 3 also shows that short-term and long-term female migrants have different characteristics, although these seem to be less clear-cut than for men. Compared to stayers, long-term migrants are more likely to be older, have grown up in a rural area, be retired and have no/primary education. Shortterm migrants are more likely to be highly educated and come from a family in which at least one parent is highly educated.

Table 3 also shows that $36.2 \%$ of stayers fall into the labour market category 'other', which mostly includes women who are looking after home or family. This compares to $25.5 \%$ for short-term migrants and $21.2 \%$ for long-term migrants. Similarly, $26.3 \%$ of stayers, $32.6 \%$ of short-term migrants and $49.8 \%$ of long-term migrants are retired. This supports the view that the majority of women who left Ireland in their youth were 'economic agents' and spent time in employment as opposed to inactivity when living abroad. This seems to be particularly the case for long-term migrants. 
Table 3 Descriptive statistics on female stayers, short-term migrants and long-term migrants

\begin{tabular}{|c|c|c|c|c|c|c|}
\hline & \multirow[t]{2}{*}{ Stayers } & \multirow[t]{2}{*}{ SD } & \multicolumn{4}{|l|}{ Migrants } \\
\hline & & & $\begin{array}{l}\text { Short-term } \\
\text { migrants }\end{array}$ & SD & $\begin{array}{l}\text { Long-term } \\
\text { migrants }\end{array}$ & SD \\
\hline \multicolumn{7}{|l|}{ Outcome variable(s): alcohol problem } \\
\hline Doctor diagnosis and/or CAGE $\geq 1$ & 0.146 & 0.353 & $0.225 * * *$ & 0.418 & 0.110 & 0.313 \\
\hline Doctor diagnosis and/or CAGE $\geq 2$ & 0.081 & 0.273 & $0.134 * * *$ & 0.341 & $0.031 * * *$ & 0.175 \\
\hline Doctor diagnosis and/or CAGE $\geq 3$ & 0.033 & 0.177 & 0.046 & 0.211 & $0.013^{*}$ & 0.112 \\
\hline \multicolumn{7}{|l|}{ Explanatory variables } \\
\hline Age & 64.333 & 10.608 & 64.821 & 9.829 & $67.455^{* * *}$ & 9.471 \\
\hline \multicolumn{7}{|l|}{ Household composition } \\
\hline Lives alone & 0.232 & 0.422 & $0.288 * *$ & 0.453 & $0.327 * * *$ & 0.470 \\
\hline Lives with spouse only & 0.356 & 0.479 & 0.386 & 0.487 & $0.422 *$ & 0.495 \\
\hline Lives with other & 0.412 & 0.492 & $0.327 * * *$ & 0.469 & $0.252 * * *$ & 0.435 \\
\hline \multicolumn{7}{|l|}{ Education } \\
\hline None/primary & 0.390 & 0.488 & $0.292 * * *$ & 0.455 & $0.447 *$ & 0.498 \\
\hline Secondary & 0.457 & 0.498 & $0.395 * *$ & 0.489 & $0.353 * * *$ & 0.479 \\
\hline Third/higher & 0.153 & 0.360 & $0.313 * * *$ & 0.464 & $0.200 * *$ & 0.401 \\
\hline \multicolumn{7}{|l|}{ Parental education } \\
\hline Both parents with low education & 0.682 & 0.466 & $0.554 * * *$ & 0.498 & 0.675 & 0.469 \\
\hline $\begin{array}{l}\text { At least } 1 \text { parent } \\
\text { secondary/tertiary education }\end{array}$ & 0.222 & 0.416 & $0.339 * * *$ & 0.474 & 0.221 & 0.416 \\
\hline 1 parent missing education & 0.095 & 0.294 & 0.107 & 0.309 & 0.104 & 0.306 \\
\hline \multicolumn{7}{|l|}{ Socioeconomic status in childhood } \\
\hline Neither parent worked & 0.057 & 0.232 & 0.052 & 0.223 & 0.051 & 0.220 \\
\hline Grew up in rural area & 0.641 & 0.480 & 0.641 & 0.480 & $0.741 * * *$ & 0.439 \\
\hline Grew up in poor family & 0.193 & 0.395 & 0.163 & 0.369 & 0.220 & 0.415 \\
\hline Poor health in childhood & 0.071 & 0.256 & 0.073 & 0.261 & 0.092 & 0.290 \\
\hline \multicolumn{7}{|l|}{ Current place of residence } \\
\hline Dublin & 0.243 & 0.429 & 0.267 & 0.443 & $0.118 * * *$ & 0.323 \\
\hline Town or city other than Dublin & 0.271 & 0.445 & 0.295 & 0.456 & 0.289 & 0.454 \\
\hline Rural area & 0.484 & 0.500 & 0.436 & 0.496 & $0.593 * * *$ & 0.492 \\
\hline \multicolumn{7}{|l|}{ Labour market status } \\
\hline Retired & 0.263 & 0.440 & $0.326^{* *}$ & 0.469 & $0.498 * * *$ & 0.501 \\
\hline Employed & 0.295 & 0.456 & 0.314 & 0.465 & $0.212 * * *$ & 0.410 \\
\hline Permanently sick or disabled & 0.052 & 0.222 & 0.072 & 0.258 & 0.059 & 0.237 \\
\hline Unemployed & 0.029 & 0.167 & 0.033 & 0.180 & 0.018 & 0.134 \\
\hline Other & 0.362 & 0.481 & $0.255^{* * *}$ & 0.436 & $0.212 * * *$ & 0.410 \\
\hline \multicolumn{7}{|l|}{ Smoking } \\
\hline Currently smokes & 0.179 & 0.383 & 0.170 & 0.376 & 0.185 & 0.389 \\
\hline Used to smoke & 0.285 & 0.451 & $0.384 * * *$ & 0.487 & $0.413 * * *$ & 0.493 \\
\hline Never smoked & 0.537 & 0.499 & $0.446 * * *$ & 0.498 & $0.402 * * *$ & 0.491 \\
\hline \multicolumn{7}{|l|}{ Negative early life events } \\
\hline Parents had alcohol/drug problem & 0.075 & 0.263 & 0.092 & 0.289 & 0.071 & 0.258 \\
\hline Parents had no alc./drug problem & 0.903 & 0.297 & 0.878 & 0.328 & 0.913 & 0.282 \\
\hline Missing information & 0.022 & 0.148 & 0.031 & 0.173 & 0.015 & 0.123 \\
\hline Physically or sexually abused & 0.083 & 0.275 & $0.126^{* * *}$ & 0.332 & 0.078 & 0.268 \\
\hline Not physically or sexually abused & 0.886 & 0.318 & $0.827 * * *$ & 0.378 & $0.842 * *$ & 0.366 \\
\hline
\end{tabular}

As was the case for men, short-term migrants are also more likely to report having been sexually or physically abused before turning 18 (8.3\% of stayers), compared to $12.6 \%$ of short-term migrants $(p<0.01)$ and $7.8 \%$ of long-term migrants. 
Table 3 (continued)

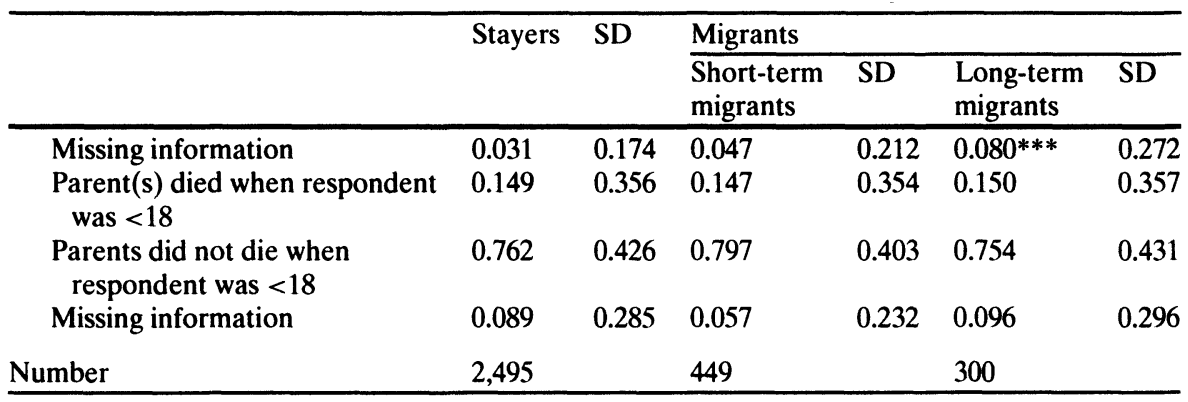

Statistically significant differences between short-term migrants and stayers and long-term migrants and stayers are reported

${ }^{*} p<0.10 ;{ }^{* *} p<0.05 ; * * * p<0.01$ (Data are weighted)

\section{Results}

\subsection{Men}

As will be seen, our empirical strategy involves three elements. We first estimate standard probit models. We then use an IV approach to adjust for potential endogeneity. Finally, we use propensity score matching.

Looking first at the standard probit model, we define the outcome variable as being one if the respondent has been diagnosed with an alcohol or substance abuse problem and/or scores 3 or more in the CAGE questionnaire. As explained above, we include two dummy variables in the model: a dummy variable equal to one if the individual is a stayer, zero otherwise (reference category); a dummy variable equal to one if the individual is a short-term migrant, zero otherwise; and a dummy variable equal to one if the individual is a long-term migrant, zero otherwise. Results are presented in Table 4. Marginal effects and standard errors are reported.

Both short-term and long-term migrants are more likely to suffer/have suffered from an alcohol problem. The marginal effects are 0.062 and 0.037 , respectively. This means that the probability of suffering/have suffered from alcohol problems is $6.2 \%$ points higher for short-term migrants than for stayers. It is $\mathbf{3 . 7} \%$ points higher for long-term migrants. Given that a relatively small proportion of the male population is affected by alcohol problems, this is a substantial difference. Put it in other terms, compared to stayers, short-term (long-term) migrants are $81.6 \%(32.7 \%)$ more likely to suffer/having suffered from an alcohol problem.

Turning to the other controls, as expected those who were physically or sexually abused in childhood or grew up in families where the parents had alcohol or drug problems, are more likely to suffer/have suffered from an alcohol problem. Alcohol problems also seem to affect particularly men who live alone, are retired and are current or past smokers. 
Table 4 Marginal effects (and standard errors) of probit model of alcohol problems (doctor diagnosis of alcohol/substance abuse and/or CAGE score $\geq 3)$ in men only $(N=2770)$

\begin{tabular}{lcc}
\hline & Marginal effect & Standard error \\
\hline Age & $-0.005^{* * *}$ & 0.001 \\
Secondary education & $0.034^{* *}$ & 0.015 \\
No/primary education & 0.022 & 0.019 \\
Lives alone & $0.045^{* *}$ & 0.018 \\
Lives with others & -0.008 & 0.013 \\
Lives in Dublin & 0.026 & 0.017 \\
Lives in a town/city other than Dublin & 0.003 & 0.014 \\
Grew up in rural area & -0.013 & 0.014 \\
Poor health in childhood & 0.007 & 0.024 \\
Grew up in a poor family & 0.002 & 0.013 \\
Neither parent worked when respondent was a child & 0.025 & 0.024 \\
Both parents with low education & 0.000 & 0.012 \\
One parent missing education & $-0.034^{*}$ & 0.017 \\
Currently smokes & $0.092^{* * *}$ & 0.023 \\
Used to smoke & $0.055^{* * *}$ & 0.014 \\
Retired & $0.055^{* * *}$ & 0.018 \\
Unemployed & 0.042 & 0.026 \\
Permanently sick or disabled & 0.046 & 0.032 \\
Other & 0.085 & 0.058 \\
Parents had an alcohol problem or used drugs & $0.057^{* *}$ & 0.023 \\
Missing information on parents alcohol/drugs problem & 0.046 & 0.072 \\
Physically or sexually abused & $0.036^{*}$ & 0.020 \\
Missing information on physical or sexual abuse & 0.024 & 0.060 \\
Parent(s) died before respondent turned 18 & 0.016 & 0.017 \\
Missing information on parents' death & 0.001 & 0.024 \\
Short-term migrant & $0.062^{* * *}$ & 0.021 \\
Long-term migrant & $0.037^{*}$ & 0.021 \\
\hline
\end{tabular}

Reference categories are as follows: third/higher level of education; lives with spouse only; lives in a rural area; at least one parent has/had secondary/tertiary education; never smoked; in employment; parents did not have an alcohol problem or used drugs; not physically or sexually abused; and parents did not die before respondent turned 18

${ }^{*} p<0.10 ;{ }^{* *} p<0.05 ;{ }^{* * *} p<0.01$ (Data are weighted)

As a robustness check, we also investigate two additional models, in which the CAGE cutoff points are set to 2 and 4, respectively. Results are presented in the electronic supplementary material (Appendix, see Tables A.1 and A.2). The results are consistent with the findings of Table 4.

As explained in the methodology section, we also attempt to adjust for endogeneity using the instrumental variable approach. As an instrument, we use the annual net migration rate for the year in which a migrant left and for the year in which a stayer was most likely to decide whether or not to migrate. For stayers, this is not observed, so we need to estimate the year. Based on those who did migrate, we compute the average age at migration stratified by sex and educational attainment and use it to estimate the age at which stayers were most likely to migrate. For example, the average age at migration for men with primary or no education was 19 years of age. For male stayers with primary or no education, we compute the migration rate for the year in which they turned 19. This is the year 'stayers were most likely to migrate', although they 
actually decided not to leave Ireland. Also, we were able to collect information of net migration rates only from 1946 onwards. Thus, we had to exclude those who either migrated before 1946 or were 'most likely to migrate' before 1946 when implementing the instrumental variable approach. This results in a loss of $3.0 \%$ of observations for men and $3.4 \%$ of observations for women.

Since both return migration, the potentially endogenous variable, and the outcome variable are binary, the model estimation strategy is not a straightforward choice. Following Wooldridge (2002) and Morris (2007), we use a bivariate probit model. This specification allows us to account for the binary nature of both return migration and the outcome variable. The key results are presented in Table 5. This time, the model is run separately for short-term and long-term migrants with the comparison group being stayers in both cases.

Looking first at the results for short-term return migrants in the second column, the lower panel shows that the net migration rate is correlated with the likelihood of the individual being a migrant. In addition, the $p$ value of the Wald test suggests that the instrument is valid. The estimated marginal effect of being a migrant on the likelihood of having or having had an alcohol problem is still positive and statistically significant. In the third column, we show the results for long-term migrants, and the same set of results emerges. The instrument is valid, and the positive estimated marginal effect remains and is statistically significant at the $10 \%$ level.

As just noted, the appropriate way of implementing an IV approach when two binary variables are involved (return migrant vs. stayer and alcohol problem or not) is a bivariate probit. However, in order to perform a second check on the validity of our instrument, we re-ran the instrumental variable analysis using linear probability models as opposed to the bivariate probit structure. In the first stage, the instrument (annual net migration rates) is an explanatory variable in a linear probability model where being a return migrant is the dependent variable. Predicted values of being a return migrant are then used in the second-stage linear probability model where having (or having had) an alcohol problem is the dependent variable. In the model for

Table 5 Impact of migration on alcohol problems of bivariate probit model in men only

\begin{tabular}{lll}
\hline & $\begin{array}{l}\text { Short-term return } \\
\text { migrants and stayers }\end{array}$ & $\begin{array}{l}\text { Long-term return } \\
\text { migrants and stayers }\end{array}$ \\
\hline Impact of (return) migration on alcohol dependence & ME $(Z$ stat $)$ \\
& $\mathrm{ME}(Z$ stat $)$ & $0.043(1.7)^{*}$ \\
Return migrant & $0.057(3.0)^{* *}$ & 0.133 \\
Rho & -0.102 & $\mathrm{X}^{2}(1)=0.195[0.659]$ \\
Wald test rho $=0[p$ value $]$ & $\mathrm{X}^{2}(1)=0.115[0.734]$ & \\
Impact of instrument on (return) migration & & Coeff $(Z$ stat $)$ \\
& Coeff $(Z$ stat $)$ & $-0.070(7.7)^{* *}$ \\
Net migration rate & $-0.053(6.7)^{* *}$ & $\mathrm{X}^{2}(1)=58.8[<0.01]$ \\
Wald test instrument $=0[p$ value $]$ & $\mathrm{X}^{2}(1)=45.4[<0.01]$ & 2,302 \\
\hline Number & 2,389 & \\
\hline
\end{tabular}

${ }^{*} p<0.10 ;{ }^{* *} p<0.01$ (Data are weighted) 
short-term male migrants, the $F$ statistic has a value of 45 and so the instrument is shown to be valid. When we run this model for long-term male migrants, the $F$ statistic is 54 .

The fact that our results are confirmed when we adjust for endogeneity is an encouraging signal that the findings from the probit model are robust. A reason for this can be found in the diagnostics reported in Table 5 which suggest that endogeneity may not have been a problem. The rho statistic presented in the upper panel in Table 5 is the correlation between the error terms in the outcome and migration equations. The Wald test of the significance of rho is a direct test for endogeneity of alcohol problems and migration. The $p$ value of this Wald test for both short-term and long-term migrant models shows that the assumption that rho is zero cannot be rejected, and, hence, we are not finding evidence of endogeneity. As we move between the univariate probit and the bivariate probit, we are correcting for something that may not be a problem, and this may be leading to the constancy in the results.

While analyses of migrant outcomes often find evidence of endogeneity, it should be noted that the outcome under investigation here is quite different in nature. More typical papers on migrants and return migrants look at the labour market outcomes. For example, Co et al. (2000) look at the earnings of return migrants in the home country relative to non-movers and find that return migrants earn more. They go on to adjust for possible endogeneity based on the expectation that the type of people who migrate may be more motivated or entrepreneurial and so would tend to earn more than non-movers regardless of whether they migrate or not. It is less clear, a priori, that migrants will differ from stayers in terms of their underlying propensity to have an alcohol problem. In addition, we should note again that well over $20 \%$ of our sample are return migrants, and so this group is closer to being a cross section of the society in question as opposed to a limited self-selected subsample. Hence, while endogeneity may be prevalent in studies on migrants, perhaps it is unsurprising that it is less of an issue in the context here.

As a final test of the robustness of the findings of higher rates of alcohol problems among men with migratory histories relative to men who stayed in Ireland, we use propensity score matching. As is well known, there are multiple ways of undertaking such matching, and the approach we have taken is to use seven approaches and to report all the results. We do this in Table 6. As can be seen, the finding of positive and significant results generally holds, and the magnitudes are not dissimilar to those reported in Tables 4 and 5.

\subsection{Women}

Given that prevalence of alcohol problems is lower for women, we first investigate the model in which alcohol problems are identified when the respondent has been diagnosed with an alcohol or substance abuse problem and/or scores two or more in the CAGE questionnaire. Results are presented in Table 7. Marginal effects and standard errors are reported. 
Table 6 Impact of return migration on alcohol problems (doctor diagnosis of alcohol/substance abuse and/or CAGE score $>=3$ ) by propensity score matching in men only

\begin{tabular}{|c|c|c|c|c|}
\hline & \multicolumn{2}{|c|}{$\begin{array}{l}\text { Short-term return } \\
\text { migrants and stayers }\end{array}$} & \multicolumn{2}{|c|}{$\begin{array}{l}\text { Long-term return } \\
\text { migrants and stayers }\end{array}$} \\
\hline & ATT & $t$ & $\overline{\mathrm{ATT}}$ & $t$ \\
\hline $\begin{array}{l}\text { Nearest neighbour without replacement } \\
\text { without calliper }\end{array}$ & $0.045^{* *}$ & 2.0 & 0.036 & 1.2 \\
\hline $\begin{array}{l}\text { Nearest neighbour without replacement } \\
\text { within calliper }\end{array}$ & $0.045^{* *}$ & 2.2 & 0.034 & 1.3 \\
\hline $\begin{array}{l}\text { Nearest neighbour with replacement } \\
\text { without calliper }\end{array}$ & 0.043 & 1.5 & $0.056^{*}$ & 1.9 \\
\hline $\begin{array}{l}\text { Nearest neighbour with replacement } \\
\text { within calliper }\end{array}$ & $0.043^{*}$ & 1.7 & $0.054^{*}$ & 1.9 \\
\hline $\begin{array}{l}5 \text { to } 1 \text { matching with replacement } \\
\text { without calliper }\end{array}$ & $0.045^{* *}$ & 2.3 & $0.046^{*}$ & 1.8 \\
\hline $\begin{array}{l}5 \text { to } 1 \text { matching with replacement } \\
\text { within calliper }\end{array}$ & $0.047 * *$ & 2.2 & $0.043^{*}$ & 1.8 \\
\hline Kernel matching & $0.051 * * *$ & 2.8 & $0.048 * *$ & 2.3 \\
\hline
\end{tabular}

Standard errors were obtained with bootstrapping. One hundred repetitions were performed for each matching algorithm

${ }^{*} p<0.10 ;{ }^{* *} p<0.05 ; * * * p<0.01$ (Data are weighted)

For women, a different picture emerges. Short-term return migrants are more likely to suffer/have suffered from an alcohol problem. The marginal effect is $0.037(p<0.05)$. On the contrary, long-term migrants are less likely to suffer/have suffered from an alcohol problem. The marginal effect is -0.045 $(p<0.01)$. This finding is in line with the conclusions of previous studies that depict a positive image of Irish women who settled down in England (i.e. long-term migrants). For example, Ryan (2007) interviewed 26 Irish nurses in Britain, who migrated in the 1950s-1970s. Most nurses interviewed worked in hospitals where Irish women were in the majority or at least a sizeable minority and, this helped them to feel part of community or less socially isolated. Also, the study from Ryan (2004) shows that being in employment, economically independent and able to send remittances home was a source of pride and self-esteem for the women interviewed. Hence, for these longer-term female migrants, it would appear that migration generated psychic benefits such as independence and control which outweighed the types of psychic costs which are typically associated with migration, such as homesickness and a sense of dislocation.

Turning to the other controls, the impact of negative early life events on the likelihood of having alcohol problems later on in life seems to be stronger for women than for men. Women who were victim of physical or sexual abuse and grew up in families where the parents had drug or alcohol problems are more likely to suffer/have suffered from an alcohol problem (the marginal effects are 0.097 and 0.049 , respectively).

As with men, we also investigate two additional models, decreasing and increasing the CAGE cutoff points (set to 1 and 3, respectively). Results are 
Table 7 Marginal effects (and standard errors) of probit model of alcohol problems (doctor diagnosis of alcohol/substance abuse and/or CAGE score $\geq 2)$ in women only $(N=3,244)$

\begin{tabular}{lcc}
\hline & Marginal effect & Standard error \\
\hline Age & $-0.004 * * *$ & 0.001 \\
Secondary education & -0.004 & 0.011 \\
No/primary education & 0.002 & 0.014 \\
Lives alone & 0.011 & 0.014 \\
Lives with others & -0.002 & 0.011 \\
Lives in Dublin & $0.047^{* * *}$ & 0.015 \\
Lives in a town/city other than Dublin & $0.023^{*}$ & 0.013 \\
Grew up in rural area & -0.015 & 0.011 \\
Poor health in childhood & 0.006 & 0.019 \\
Grew up in a poor family & -0.018 & 0.012 \\
Neither parent worked when respondent was a child & 0.011 & 0.023 \\
Both parents with low education & $-0.019 *$ & 0.012 \\
One parent missing education & -0.023 & 0.014 \\
Currently smokes & $0.097^{* * *}$ & 0.019 \\
Used to smoke & $0.057^{* * *}$ & 0.012 \\
Retired & -0.010 & 0.014 \\
Unemployed & -0.016 & 0.022 \\
Permanently sick or disabled & -0.008 & 0.019 \\
Other & $-0.019 *$ & 0.012 \\
Parents had an alcohol problem or used drugs & $0.097^{* * *}$ & 0.022 \\
Missing information on parents alcohol/drugs problem & 0.023 & 0.043 \\
Physically or sexually abused & $0.049^{* * *}$ & 0.018 \\
Missing information on physical or sexual abuse & 0.030 & 0.035 \\
Parent(s) died before respondent turned 18 & $-0.020^{*}$ & 0.012 \\
Missing information on parents' death & 0.040 & 0.026 \\
Short-term migrant & $0.037^{* *}$ & 0.016 \\
Long-term migrant & $-0.045^{* * *}$ & 0.012 \\
\hline
\end{tabular}

Reference categories are as follows: third/higher level of education; lives with spouse only; lives in a rural area; at least one parent has/had secondary/tertiary education; never smoked; in employment; parents did not have an alcohol problem or used drugs; not physically or sexually abused; and parents did not die before respondent turned 18

${ }^{*} p<0.10 ; * *<0.05 ; * * * p<0.01$ (Data are weighted)

Table 8 Impact of migration on alcohol problems by bivariate probit, in women only

\begin{tabular}{lll}
\hline & $\begin{array}{l}\text { Short-term return } \\
\text { migrants and stayers }\end{array}$ & $\begin{array}{l}\text { Long-term return } \\
\text { migrants and stayers }\end{array}$ \\
\hline Impact of (return) migration on alcohol dependence & ME ( $Z$ stat $)$ \\
& $\operatorname{ME~}(Z$ stat $)$ & $-0.037(2.04)^{*}$ \\
Return migrant & $0.040(2.1)^{*}$ & 0.372 \\
Rho & -0.061 & $X^{2}(1)=1.081[0.298]$ \\
Wald test rho $=0[p$ value $]$ & $X^{2}(1)=0.017[0.897]$ & Coeff $(Z$ stat $)$ \\
Impact of instrument on (return) migration & & $-0.056(6.3)^{* *}$ \\
& Coeff $(Z$ stat $)$ & $X^{2}(1)=39.8[<0.01]$ \\
Net migration rate & $-0.027(3.3)^{* *}$ & 2,704 \\
Wald test instrument $=0[p$ value $]$ & $X^{2}(1)=11.1[<0.01]$ & \\
Number & 2,845 & \\
\hline
\end{tabular}

$* p<0.05 ; * * p<0.01$ (Data are weighted) 
Table 9 Impact of return migration on alcohol problems (doctor diagnosis of alcohol/substance abuse and/or CAGE score $\geq 2$ ) by propensity score matching in women only

\begin{tabular}{|c|c|c|c|c|}
\hline & \multicolumn{2}{|c|}{$\begin{array}{l}\text { Short-term return } \\
\text { migrants and stayers }\end{array}$} & \multicolumn{2}{|c|}{$\begin{array}{l}\text { Long-term return } \\
\text { migrants and stayers }\end{array}$} \\
\hline & $\overline{\mathrm{ATT}}$ & $t$ & ATT & $t$ \\
\hline $\begin{array}{l}\text { Nearest neighbour without replacement } \\
\text { without calliper }\end{array}$ & $0.058 * * *$ & 2.6 & -0.033 & -1.6 \\
\hline $\begin{array}{l}\text { Nearest neighbour without replacement } \\
\text { within calliper }\end{array}$ & $0.056^{* *}$ & 2.1 & -0.034 & -1.6 \\
\hline $\begin{array}{l}\text { Nearest neighbour with replacement } \\
\text { without calliper }\end{array}$ & $0.065^{* *}$ & 2.3 & -0.033 & -1.4 \\
\hline $\begin{array}{l}\text { Nearest neighbour with replacement } \\
\text { within calliper }\end{array}$ & $0.065^{* *}$ & 2.3 & -0.034 & -1.4 \\
\hline $\begin{array}{l}5 \text { to } 1 \text { matching with replacement } \\
\text { without calliper }\end{array}$ & 0.016 & 1.1 & $-0.035^{* *}$ & -2.1 \\
\hline $\begin{array}{l}5 \text { to } 1 \text { matching with replacement } \\
\text { within calliper }\end{array}$ & 0.016 & 1.0 & $-0.035^{*}$ & -1.7 \\
\hline Kernel matching & 0.019 & 1.6 & $-0.038 * * *$ & -2.8 \\
\hline
\end{tabular}

Standard errors were obtained with bootstrapping. One hundred repetitions were performed for each matching algorithm

$* p<0.10 ; * * p<0.05 ; * * * p<0.01$

presented in the electronic supplementary material (Appendix, see Tables A.3 and A.4). The results are consistent with the findings in Table 6.

Just as we addressed the issue of potential endogeneity with respect to men, we also did this for women using bivariate probit models. The results are shown in Table 8. Looking first at the column labelled short-term return migrants and stayers, we can see that the instrument is valid. We can also see that the positive and significant estimated marginal effect remains. Looking at long-term female migrants, again, the instrument is valid, and the negative and statistically significant estimated marginal effect remains. We also checked the validity of the instrument using linear probability models. The $F$ Statistic in the short-term model was 10 ; in the long-term model, the $F$ statistic was 29. Hence, the validity of the instrument is confirmed.

The propensity score analysis for women is presented in Table 9. Once again, we see positive estimated effects for short-term female migrants, although the statistical significance dips in a limited number of cases. We also see again the negative estimated effects for long-term female migrants and so the apparent psychic benefits for this group.

\section{Are return migrants 'failed migrants'?}

According to the results of our model, short-term and long-term male return migrants and short-term female return migrants are more likely to suffer/have suffered from alcohol problems than stayers. One could argue that the higher prevalence of alcohol problems for Irish return migrants is due to the fact that those who returned home are 'failed migrants', i.e. those who were not able to 
settle down/build a new life abroad and hence returned to Ireland. In the first wave of TILDA, return migrants were not asked why they returned home. Hence, we do not have information on the reasons that triggered their return to Ireland.

Ideally, we would include a third category of migrants in our analysis: 'migrants who did not return to Ireland' and compare mental health outcomes of Irish stayers, Irish return migrants and Irish non-returning migrants. Unfortunately, to our knowledge, a dataset which includes both a sufficiently high number of older Irish migrants living abroad and the variables employed in our model is not available.

However, we can use information from the 1997, 1998, 1999 and 2004 waves of the Health Survey for England (HSE). The HSE is an annual survey designed by the Department of Health aimed at providing regular information on various aspects of the English population's health. In the 1997, 1998, 1999 and 2004 waves, respondents were asked if they were born in Ireland. Twentyseven Irish men and 28 Irish women aged 50 and above were interviewed in 1997, compared to 47 men and 60 women in 1998, 90 men and 125 women in 1999, and 114 men and 138 women in 2004.

Drinking patterns is one of the HSE survey's core topics. The CAGE questionnaire was included in the 1997 and 1998 waves of the survey. Unfortunately, the small number of Irish-born men and women interviewed in 1997 and 1998 does not allow a thorough investigation of the CAGE module for Irish non-returning migrants living in England. However, we can still use information on alcohol consumption and frequency. In the HSE, respondents are asked whether they drink alcohol or not. If they do, they are asked about how often they have had an alcoholic drink of any kind in the last 12 months. Similar questions are asked in TILDA.

In Table 10, we compare the shares of Irish stayers, Irish return migrants and Irish non-returning migrants aged 50 and above who report to be drinking an alcoholic drink almost every day, at least three times per week or once

Table 10 Frequency of alcohol consumption, Irish stayers, non-returning-migrants and return migrants aged $50+$

\begin{tabular}{|c|c|c|c|c|c|c|}
\hline & \multicolumn{3}{|l|}{ Men } & \multicolumn{3}{|l|}{ Women } \\
\hline & $\begin{array}{l}\text { Almost } \\
\text { every } \\
\text { day } \\
(\%)\end{array}$ & $\begin{array}{l}\text { At least } \\
3 \text { days } \\
\text { per week } \\
(\%)\end{array}$ & $\begin{array}{l}\text { Once per } \\
\text { month } \\
\text { maximum } \\
(\%)\end{array}$ & $\begin{array}{l}\text { Almost } \\
\text { every } \\
\text { day } \\
(\%)\end{array}$ & $\begin{array}{l}\text { At least } \\
3 \text { days } \\
\text { per week } \\
(\%)\end{array}$ & $\begin{array}{l}\text { Once per } \\
\text { month } \\
\text { maximum } \\
(\%)\end{array}$ \\
\hline $\begin{array}{l}\text { HSE non-returning migrants } \\
(1997-1999 \text { and 2004) }\end{array}$ & 17.3 & 37.2 & 24.2 & 8.3 & 20.5 & 42.5 \\
\hline $\begin{array}{l}\text { HSE non-returning } \\
\text { migrants ( } 2004 \text { only) }\end{array}$ & 14.0 & 32.5 & 28.1 & 11.6 & 26.8 & 39.9 \\
\hline $\begin{array}{l}\text { TILDA return migrants } \\
(2009-2011)\end{array}$ & 10.1 & 30.2 & 26.2 & 5.6 & 19.2 & 40.2 \\
\hline TILDA stayers (2009-2011) & 7.4 & 26.0 & 32.1 & 3.2 & 15.1 & 45.2 \\
\hline
\end{tabular}

Sources: 1997, 1998, 1999 and 2004 waves of Health Survey for England; TILDA wave 1 
per month at the most. The table shows that the shares of those drinking almost every day/at least three times per week are highest for both male and female non-returning migrants and lowest for Irish stayers. Similarly, the shares of those drinking at the most once per month are highest for Irish stayers and lowest for Irish non-returning migrants. According to these findings, the assumption that the prevalence of alcohol problems is higher for Irish return migrants because they are 'failed migrants' does not hold.

\section{Conclusions}

Our objective in this paper was to explore whether or not we could find evidence of the existence of psychic costs of migration. Using alcohol dependence as an indicator of psychological stresses and problems over the life course, we compared older Irish adults living in Ireland and found the following. Using standard probit regressions, instrumental variable techniques and propensity score matching, we have found a consistent set of results. For men, former migrants were found to exhibit a greater likelihood of having had alcohol problems at some stage relative to stayers. This was also found for women who had lived away for 10 years or less. However, women who had lived away for 10 years or more were less likely to have suffered from alcohol problems. This seems to suggest that for women who lived abroad for a long period of time, migration generated 'psychic benefits' rather than psychic costs. Given that we were able to control for traumatic events earlier in life and that IV methods are used to adjust for potential endogeneity, the findings for men do appear to support the notion that migration caused stress in the lives of these men which led to a higher level of alcohol dependence when compared to men who stayed in Ireland. The findings for women who lived away for 10 years or more offer a fascinating contrast. Their lower levels of alcoholism suggest a very favourable migration experience relative to Irish women who remained in Ireland. Drawing on sociological literature, it seems that migration gave some Irish women a greater sense of economic independence in particular, and this might explain the apparent psychic benefits of migration. For men and for short-term female migrants, the more usual psychic costs of migration, such as homesickness and dislocation, appear to have dominated.

The presence of psychic costs for migrants can have many implications and may help to explain some of the research findings on immigrants. At the most basic level, our findings help to explain why outward migration is often a lot lower than might be expected on given income differentials between countries. Return migration is often higher than might be explained by standard models. This return migration can be explained, in part, using the psychic costs argument, if such costs are under-estimated ex ante.

A constant finding in the economics literature on migration is the lower earnings of immigrants and generally poorer labour market outcomes. Clearly, mental health problems tend to work against success in the labour market and so may add to whatever other obstacles that migrants face. Finally, for 
countries such as Ireland with a large proportion of former migrants, the presence of mental stress among this group will have implications for public health delivery.

Acknowledgements We thank the two anonymous referees and the editor, Klaus $F$. Zimmermann, for their insightful comments and suggestions. We also thank the seminar participants at the University of Strathclyde, Swansea University and the National University of Ireland Maynooth and the delegates at the 2011 Irish Economic Association Annual Conference in Limerick and the 2nd TEMPO Conference on International Migration in Vienna. Finally, we also thank Brendan Walsh for the help in sourcing historic data on Irish migration flows. All errors are our own.

\section{References}

Aichberger MC, Schouler-Ocak M, Mundt A, Busch MA, Nickels E, Heimann HM, Ströhle A, Reischies FM, Heinz A, Rapp MA (2010) Depression in middle-aged and older first generation migrants in Europe: results from the Survey of Health, Ageing and Retirement in Europe (SHARE). Eur Psychiatr 25(8):468-475

Arnow BA (2004) Relationships between childhood maltreatment, adult health and psychiatric outcomes, and medical utilization. J Clin Psychiat 65(Suppl 12):10-15

Barrett A (2005) Irish migration: characteristics, causes and consequences. In: Zimmermann KF (ed) European migration: what do we know? Oxford University Press, Oxford, pp 89-112

Barrett A, Goggin J (2010) Returning to the question of a wage premium for returning migrants. Natl Inst Econ Rev 213(1):R43-R51

Batten SV, Aslan M, Maciejewski PK, Mazure CM (2004) Childhood maltreatment as a risk factor for adult cardiovascular disease and depression. J Clin Psychiatry 65:249-254

Bernadt MW, Taylor C, Mumford J, Smith B, Murray RM (1982) Comparison of questionnaire and laboratory tests in the detection of excessive drinking and alcoholism. Lancet 1:325-328

Bhugra D (2004) Migration and mental health. Acta Psychiatr Scand 109:243-258

Bradley KA, Korell K, McDonell MB, Malone T, Fihn SD (1998) Screening for problem drinking: comparison of CAGE and AUDIT. J Gen Intern Med 13:379-388

Cerase FP (1970) Nostalgia or disenchantment: considerations on return migration. In: Tomasi SM, Engel MH (eds) The Italian experience in the US. Center for Migration Studies, New York, pp 217-239

Cerase FP (1974) Expectations and reality: a case study of return migration from the United States to Southern Italy. Int Migr Rev 8(26):245-262

Christou A (2006) American dreams and European nightmares: experiences and polemics of second-generation Greek-American returning migrants. J Ethn Migr Stud 32(5):831-845

Co CY, Gang IN, Myeong-Su Y (2000) Returns to returning. J Popul Econ 13:57-79

Cochrane B, Bal SS (1989) Mental hospital admission rates of migrants to England: a comparison of 1971 and 1981. Soc Psychiatry Psychiatr Epidemiol 24(1):2-11

Coid JW, Kirkbride JB, Barker D, Cowden F, Stamps R, Yang M, Jones PB (2008) Raised incidence rates of all psychoses among migrant groups: findings from the East London first episode psychosis study. Arch Gen Psychiatry 65(11):1250-1258

Commander MJ, Odell S, Sashidharan SP, Surtees PG (1999) Psychiatric morbidity in people born in Ireland. Soc Psychiatry Psychiatr Epidemiol 34(11):565-569

Constable N (1999) At home but not at home: Filipina narratives of ambivalent returns. Cult Anthropol 14(2):203-228

Daniels M (1993) Exile or opportunity? Irish nurses and midwives in Britain. Institute of Irish Studies, Liverpool

Draper B, Pfaff JJ, Pirkis J, Snowdon J, Lautenschlager NT, Wilson I, Almeida OP (2008) Longterm effects of childhood abuse on the quality of life and health of older people: results from the depression and early prevention of suicide in general practice project. $\mathrm{J}$ Am Geriatr Soc 56(2):262-71 
Ewing JA, Rouse BA (1970) Identifying the hidden alcoholic. In: Proceedings of the 29th international congress on alcohol and drug dependence, 3 February 1970, Sydney, Australia

Ewing JA (1984) Detecting alcoholism: the CAGE questionnaire. JAMA 252(14):1905-1907

Ewing JA (1998) Screening for alcoholism using the CAGE (letter). JAMA 280(22):1904

Faini R, Venturini A (2010) Development and migration: lessons from Southern Europe. In: Epstein GS, Gang IN (eds) Migration and culture (frontiers of economics and globalization, volume 8). Emerald Group Publishing Limited, Bingley, UK, pp 105-136

Gmelch G (1986) The readjustment of return migrants in Western Ireland. In: King R (ed) Return migration and regional economic problems. Croom Helm, London, pp 152-170

Gmelch G (1987) Return migration to rural Ireland. In: Buechler H (ed) Migrants in Europe: the role of family, labor and politics. Greenwood, New York, London, pp 265-281

Harrison L, Carr-Hill R (1992) Alcohol and disadvantage among the Irish in Britain. Federation of Irish Societies, London

Hughes JG, Walsh BM (1976) Migration flows between Ireland, the United Kingdom and the rest of the world, 1966-1971. Eur Demogr Inf Bull 7:125-149

Kitchens JM (1994) Does this patient have an alcohol problem? JAMA 272(22):1782-1787

Kraaij V, Arensman E, Spinhoven P (2002) Negative life events and depression in elderly persons: a meta-analysis. Gerontol B Psychol Sci Soc Sci 57(1):87-94

Leavey G, Sembhi S, Livingston G (2004) Older Irish migrants living in London: identity, loss and return. J Ethn Migr Stud 30(4):763-779

Long L, Oxfeld E (2004) Coming home: refugees, migrants and those who stayed behind. University of Pennsylvania Press, Philadelphia

Mayfield D, McLeod G, Hall P (1974) The CAGE questionnaire: validation of a new alcoholism screening instrument. Am J Psychiatr 131(10):1121-1123

McGrath F (1991) The economic, social and cultural impacts of return migration to Achill Island. In: King R (ed) Contemporary Irish migration. Geographical Society of Ireland, Dublin, pp 55-69

Morris S (2007) The impact of obesity on employment. Labour Econ 14:413-433

Mullen K, Williams R, Hunt K (1996) Irish descent, religion, and alcohol and tobacco use. Addiction 91(2):243-254

National Center of Addiciton and Substance Abuse at Columbia University (2000) Missed opportunity: national survey of primary care physicians and patients on substance abuse. http://www.casacolumbia.org/pplsearch.aspx. Accessed 23 July 2012

Nazroo J (1997) Ethnicity and mental health. PSI, London

NESC (National Economic and Social Council) (1991) The economic and social implications of emigration. Dublin, National Economic and Research Council. http://files.nesc.ie/nesc reports/en/NESC_90_1991.pdf. Accessed 13 Aug 2012

Odegaard O (1932) Emigration and insanity. Acta Psychiatr Neurol 4(1):206

Pearson M, Madden M, Greenslade L (1991) Generations of an invisible minority: the health and well-being of the Irish in Britain. Institute of Irish Studies, Liverpool

Ryan L (2004) Family matters: (e)migration, familial networks and Irish women in Britain. Sociol Rev 52(3):351-370

Ryan L (2007) Who do you think you are? Irish nurses encountering ethnicity and constructing identity in Britain. Ethn Racial Stud 30(3):416-438

Sexton J (1996) Report to OECD continuous reporting system on migration (SOPEMI). Economic and Social Research Institute, Dublin

Silveira E, Skoog I, Sundh V, Allebeck P, Steen B (2002) Health and well-being among 70-yearold migrants living in Sweden-results from the $\mathbf{H} 70$ gerontological and geriatric population studies in Gotenborg. Soc Psychiatry Psychiatr Epidemiol 37:13-22

Sjaastad L (1962) The costs and returns of human migration. J Polit Econ 70:80-93

Springer KW, Sheridan J, Kuo D, Carnes M (2003) The long-term health outcomes of childhood abuse. J Gen Intern Med 18(10):864-870

Walter B (1989) Irish women in London: the Ealing dimension. Ealing Women's Unit, London

Wooldridge JM (2002) Econometric analysis of cross section and panel data. MIT, Cambridge, MA 